\title{
O território das onças e a aldeia dos brancos: lugar e perspectiva entre os Karajá de Buridina (Brasil Central)
}

Le territoire des jaguars et le village des Blancs : lieu et perspective chez les Karajá de Buridina (Brésil central)

Jaguars' territory and Whites' village: place and perspective among the Karajá of Buridina (Central Brazil)

\section{Eduardo S. Nunes}

\section{OpenEdition}

\section{Journals}

\section{Edição electrónica}

URL: https://journals.openedition.org/jsa/12889

DOI: 10.4000/jsa. 12889

ISSN: 1957-7842

\section{Editora}

Société des américanistes

\section{Edição impressa}

Data de publição: 30 dezembro 2013

Paginação: 135-164

ISSN: 0037-9174

Refêrencia eletrónica

Eduardo S. Nunes, "O território das onças e a aldeia dos brancos: lugar e perspectiva entre os Karajá de Buridina (Brasil Central) », Journal de la Société des américanistes [En ligne], 99-2 | 2013, mis en ligne le 01 janvier 2016, consulté le 03 septembre 2022. URL : http://journals.openedition.org/jsa/ 12889 ; DOI : https://doi.org/10.4000/jsa.12889 


\title{
O TERRITÓRIO DAS ONÇAS E A ALDEIA DOS BRANCOS: LUGAR E PERSPECTIVA ENTRE OS KARAJÁ DE BURIDINA (BRASIL CENTRAL)
}

\author{
Eduardo S. NUNES *
}

\begin{abstract}
O presente artigo descreve os deslocamentos dos Karajá de Buridina (Brasil Central) rumo a dois tipos de lugares, o mato e a cidade, os territórios (hãwa) das onças e dos brancos, respectivamente. Esses trânsitos envolvem uma dinâmica de transformação, as afecções, capacidades e disposições corporais dos Karajá mudando quando caminham no mato e quando vão à cidade. Argumento que os lugares e as pessoas se constituem reciprocamente, de modo que os lugares estabilizam a perspectiva dos seres seus habitantes. Assim, estar em um lugar implica estabelecer uma relação com a perspectiva dos seres para os quais aquele lugar é uma aldeia ou um território. [Palavras chave: lugar, perspectiva, Karajá, transformação, socialidade.]
\end{abstract}

Le territoire des jaguars et le village des Blancs : lieu et perspective chez les Karajá de Buridina (Brésil central). Cet article décrit les déplacements des Karajá de Buridina (Brésil central) vers deux types de lieux, la forêt et la ville, correspondant respectivement au territoire ( $h \tilde{a} w a$ ) des jaguars et à celui des Blancs. Cette circulation implique une transformation des affects, des capacités et des dispositions des corps Karajá lorsqu'ils marchent dans la forêt ou se rendent en ville. L'argument est que les lieux et les personnes se constituent réciproquement, de sorte que les lieux stabilisent la perspective des êtres qui les habitent. Ainsi, être dans un lieu implique d'établir une relation dans la perspective des êtres pour lesquels ce lieu est un village ou un territoire. [Mots-clés : lieu, perspective, Karajá, transformation, socialité.]

Jaguars' territory and Whites' village: place and perspective among the Karaja of Buridina (Central Brazil). The present paper describes the movements of the Karajá of Buridina (Central Brazil) towards two kinds of places, the bush and the city, territories (hãwa) of the jaguars and of the Whites, respectively. These movements involve a dynamics of transformation, a change in the affections, capabilities and bodily dispositions of the Karajá when they walk in the bush and when they go to the city. I argue that places and persons mutually constitute one another, so that places stabilize

* Programa de Pós-Graduação em Antropologia Social (PPGAS), Departamento de Antropologia, Universidade de Brasília (UnB), Brasília, Brasil [eduardo.s.nunes@hotmail.com].

Journal de la Société des Américanistes, 2013, 99-2, pp. 135-164. (C) Société des Américanistes. 
the perspective of the beings that inhabit it. Being in a place, then, imply establishing a relation with the perspective of the beings to whom that place is a village, or a territory. [Key words: place, perspective, Karajá, transformation, sociality.]

\begin{abstract}
Pour les primitifs, la représentation de l'espace, comme celle du temps, si tant est qu'ils en aient une expresse, est surtout qualitative. Les régions de l'espace ne sont pas conçues, ni proprement représentées, mais plutôt senties dans des ensembles complexes, où chacune est inséparable de ce qui l'occupe. Chacune participe des animaux réels ou mythiques qui y vivent, des plantes qui y poussent, des tribus qui l'habitent, des vents et des orages qui en viennent, etc.
\end{abstract}

(Lévy-Bruhl 1922)

Minha etnografia na aldeia karajá Buridina envolveu, desde o princípio, o trânsito a dois tipos de lugar visitados com frequência pelos indígenas, a cidade e o mato. Buridina está incrustada no centro da turística cidade de Aruanã (estado de Goiás - GO), e os Karajá vão à cidade cotidianamente. Por outro lado, a pesca é uma atividade muito importante, o que leva os indígenas (sobretudo os homens) a transitar pelo mato regularmente. Essas incursões a lugares habitados por seres outros sempre me chamaram atenção pela transformação que elas suscitam nos indígenas. Transformação de seus corpos: de suas roupas, no regime de comunicação, nos movimentos, etc. Esse artigo é uma reflexão sobre esses trânsitos, as transformações por eles implicadas, e a articulação dessas questões com os lugares. Centrando-me no conceito de hãwa, " aldeia/território/lugar », argumento que a relação de alguém com uma « aldeia » ou um « território » que não o seu é, fundamentalmente, uma relação com o ponto de vista dos seres habitantes daquele lugar, os seres para os quais aquele lugar é, justamente, uma « aldeia » ou um " território ». Portanto, essa relação, esse trânsito, geralmente implica uma mudança de ponto de vista, pois os lugares - e esse é o argumento central - estabilizam a perspectiva dos seres seus habitantes.

\title{
A aldeia Buridina
}

Os Karajá, grupo falante de uma língua tardiamente classificada como pertencente ao tronco Macro-Jê - o inỹrybe ${ }^{1}$-, ocupam imemorialmente a calha do Rio Araguaia. A maior parte de suas aldeias está localizada na Ilha do Bananal (estado do Tocantins - TO). Buridina é a aldeia situada mais à montante deste território, em um trecho onde o Araguaia faz a divisa entre os estados de Goiás (GO) - e é deste lado que a aldeia está - e Mato Grosso (MT) (Figura 1). No início do século Xx, Buridina estava situada ao lado - separada apenas pelo córrego Bandeirantes - de um presídio, chamado Santa Leopoldina, 


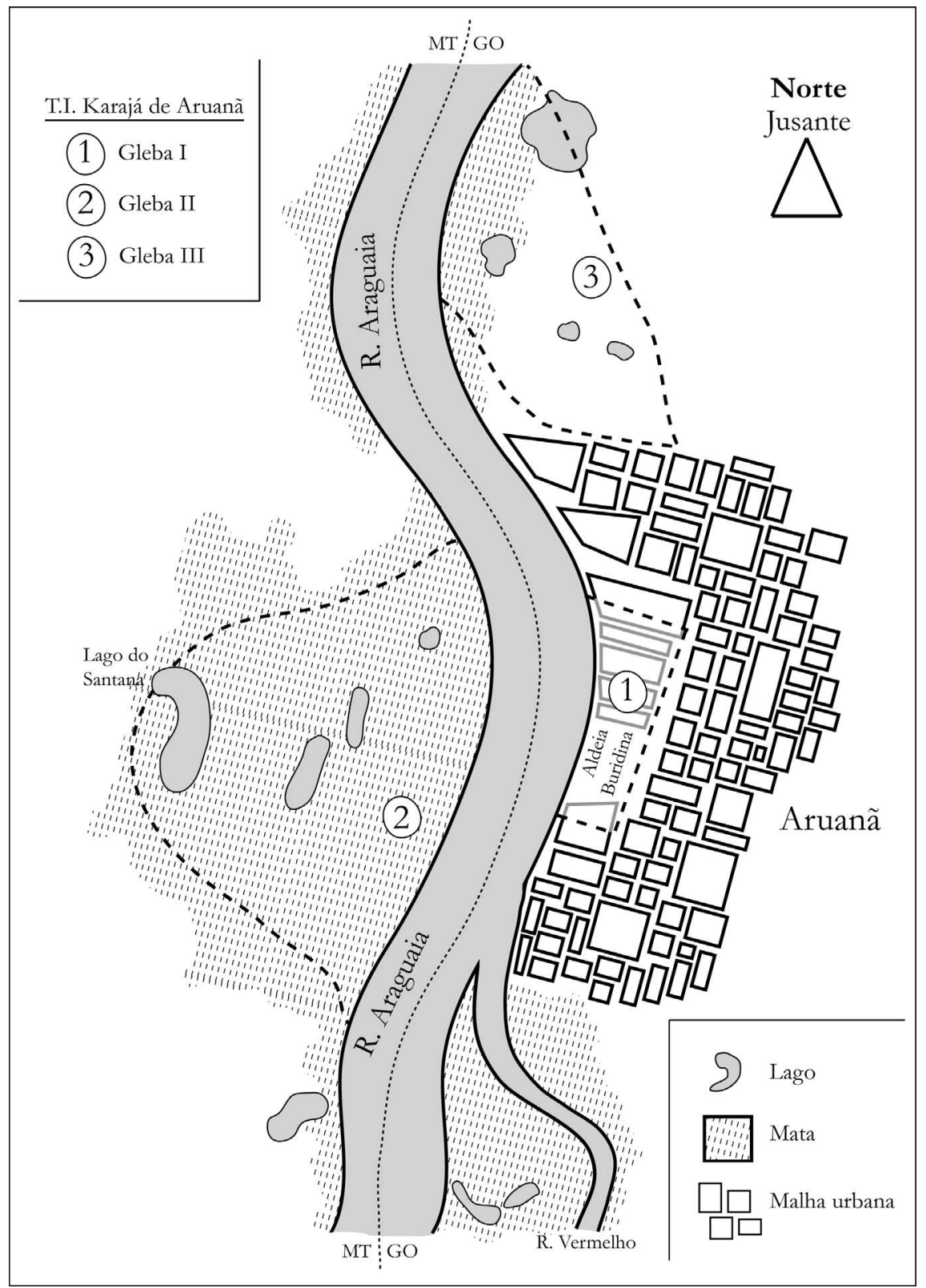

FIG. 1 - Crosquis da Terra Indígena Karajá de Aruanã. 
em torno do qual cresceu um vilarejo homônimo. Tendo sido outrora a maior aldeia Karajá de que já se teve notícia, na década de 1940 dois incidentes relacionados à feitiçaria dispersam quase toda sua população. A aldeia se vê, então, resumida a um homem, Jacinto Maurehi, que opta por ficar ali e reúne em torno de si, nas décadas subseqüentes, um pequeno contingente de parentes, em torno do qual ela se reestruturou. Na década de 1970, a já então cidade de Aruanã começa a se expandir e atravessa o córrego Bandeirantes. Cerca de uma década depois, a aldeia já está, exceção feita ao lado do rio, rodeada pela malha urbana, restrita a um espaço de aproximadamente $10.000 \mathrm{~m}^{2}$.

Os Karajá sempre manifestaram sua vontade de permanecer no local onde estavam, mas o projeto do órgão indigenista do Estado brasileiro era tentar transferir a pequena população para junto de seus parentes na Ilha do Bananal. O órgão não lhes ofereceu praticamente nenhuma assistência até 1986, quando cede a pressões tanto dos índios quanto de alguns regionais e dá início à demarcação. O processo gerou diversos conflitos e se arrastou por muitos anos: o relatório antropológico que fundamentou a delimitação da área data de 1992; sua aprovação data de 1995, e, em 2000, a Terra Indígena Karajá de Aruanã foi homologada, sendo por fim registrada como "próprio nacional» em 2001. A terra, devido à localização da aldeia dentro da malha urbana, não foi demarcada em área contínua, mas sim dividida em três glebas. A Gleba I corresponde a uma faixa de $100 \mathrm{~m}$ de cumprimento, localizada no centro da cidade, entre sua principal avenida e o rio Araguaia, somando 14 ha; é aí que se situa a aldeia, que conta cerca de 200 pessoas. A Gleba II, uma área de 893 ha, situa-se em território do estado do Mato-Grosso, do outro lado do rio, em frente à aldeia e ao centro de Aruanã. Quando da cheia do rio, essa área fica parcialmente alagada, motivo pelo qual a cobertura vegetal, uma mata densa e alta, nunca foi derrubada para ser transformada em fazenda; o local não é usado para moradia, apenas para coleta de frutos, para a caça e, principalmente, para a pesca. Em uma situação oposta se encontra na Gleba III (705 ha), situada no limite norte da cidade, cujo cerrado foi todo transformado em pasto, restando da vegetação original apenas a mata ciliar, também alagada na cheia do rio; essa área é utilizada pela maioria apenas como espaço de plantio, mas há alguns indígenas que moram ali (aproximadamente 41 pessoas, sendo que 23 destes compõem uma parentela que veio da Ilha do Bananal há alguns anos) ${ }^{2}$.

O Rio Araguaia, em diversos locais ao longo de sua calha, atrai um imenso fluxo de turistas interessados nas belezas naturais do rio, tanto para descanso e lazer como para a pesca esportiva. No período da seca o nível da água baixa, deixando à mostra grandes praias de areia branca. Aruanã é provavelmente a cidade na beira do Araguaia onde o turismo é mais intenso. Há inúmeras pousadas, hotéis, e mansões de veraneio, algumas delas voltadas para um turismo de luxo, com diárias que chegam a custar cerca de 350.00 reais. Durante o mês de julho, a prefeitura da cidade promove a «Temporada Turística de Aruanã », 
oferecendo shows gratuitos à população e aos visitantes todas as noites de sexta-feira e sábado durante esse mês. Índios e regionais se referem a essa época simplesmente como « temporada ». A prefeitura estima que, só no mês de julho, mais de 600.000 pessoas passem pela cidade que, segundo o último censo, conta apenas 7.496 pessoas. Outros períodos, como o carnaval, feriados, o aniversário da cidade e o mês de maio (quando os cardumes que sobem o rio anualmente estão passando pela região), também atraem turistas para Aruanã, embora em quantidade muito menor que na temporada.

\section{O TERRITÓRIO DAS ONÇAS}

Comparados a grupos Tupi e Gê, por exemplo, os Karajá dedicam pouca atenção à agricultura e à caça. A pesca é sua atividade mais valorizada, tanto simbólica quanto quantitativamente. Eles exploram o curso principal do rio assim como os muitos lagos que compõem o sistema hídrico do Araguaia. $\mathrm{O}$ Lago do Santana é um dos principais lagos dentro da Terra Indígena (Gleba II) utilizados pelos Karajá de Buridina para a pesca - é o maior deles (Figura 1). Para chegar até lá, eles, após cruzar o rio em suas canoas, geralmente atravessam a pé uma trilha de cerca de $3.5 \mathrm{~km}$ que se esconde sob a mata alta. Acompanhei os Karajá em várias dessas expedições de pesca no Lago do Santana e na grande maioria delas as onças (halòè, ố; halòkòè, o $)^{3}$ se fizeram notar pelos seus esturros ${ }^{4}$. Ainda que nessa região haja onças nos vários pedaços de mata ao longo da margem do rio, não é frequente escutar sua presença. Se nesse lugar no Mato Grosso, a Gleba II da Terra Indígena, quase sempre se ouve seu esturro, é porque « ali é o território das onças », dizem os Karajá.

De toda a multiplicidade de seres outros com os quais os Karajá de Buridina estão em relação, as onças são objeto de uma formulação perspectivista mais explícita. Quando se encontra com um desses felinos frente a frente, se ele está com o rabo levantado, é sinal de que vai atacar. O ataque sempre se dá em três movimentos: o predador dá um pequeno salto em direção à vítima, de modo que ela pode chegar para trás e escapar. Depois repete o mesmo movimento. $\mathrm{O}$ terceiro salto, porém, é fatal - « a onça pula três vezes, o terceiro é para pegar », dizem. Mas as onças têm um « segredo »: quando se troca olhares com ela, nesta situação prototípica do ataque felino, é preciso mostrar que não se tem medo. Se a pessoa demonstrar coragem de enfrentá-la, não demonstrar medo, " ela amansa », abaixando o rabo. " Aí você faz o que quiser com ela », me disse um homem. Nas histórias de homens valentes que lograram, nessas situações, se impor e fazer a onça abaixar o rabo com uma mera troca de olhares, os protagonistas venceram seu adversário felino com extrema facilidade, brincando com ele, pegando-o pelo rabo, fazendo-o fugir amedrontado, etc. Se o medo transparecer, porém, ela ataca. Em um encontro com uma onça no meio do mato, 
só pode haver um sujeito, um predador. O outro é sempre uma presa em uma situação de vulnerabilidade passiva, a mercê do que o sujeito resolverá lhe fazer. Se a onça logra impor seu ponto de vista, resta torcer para que se esteja em um dia de sorte, que a onça não esteja com fome ou " parida " ${ }^{5}$ e que ela o deixe fugir. O ponto é importante, pois é a onça que deixa sua presa fugir, enfatizam os Karajá, nunca a presa que, num ato de astúcia, logra escapar. Se é o homem, porém, que impõe sua perspectiva, é a onça que precisará contar com a sorte. A estrutura do encontro é sempre a mesma, e só há duas posições possíveis: a de sujeito-predador e a de objeto-vítima ${ }^{6}$.

Se os Karajá contam histórias sobre alguns homens valentes que « pegavam onça pelo rabo ${ }^{7}{ }^{7}$, no mato, essa façanha só pode mesmo depender desse jogo de perspectivas no encontro face a face, pois ninguém nunca avista uma onça, a não ser que ela se deixe ver. Mesmo caminhando sobre as folhas e galhos secos que cobrem o chão da mata, o único sinal da presença do grande mamífero é um barulho que ele faz com as orelhas - « ela quebra a orelha », dizem -, produzindo um estalido algo semelhante a um graveto sendo quebrado. Mas nunca se escuta seu caminhar. No mato, a onça está sempre observando os humanos que ali estão e que nunca podem vê-la, exceto quando ela própria se dá a ver. Certa vez, um Karajá estava pescando no Lago do Santana e quando a caixa de isopor que levara para armazenar o pescado refrigerado encheu, ele resolveu voltar até sua casa e esvaziá-la para que pudesse retornar ao lago e continuar pescando. E assim o fez. Quando chegou novamente ao início da trilha, cerca de meia hora depois de tê-la deixado, havia um rastro de onça ao longo de todo o trajeto que ele percorrera. A onça estava em seu encalço, apenas não quis se deixar ver, eis a conclusão dos indígenas.

Quando os Karajá caminham pelo território das onças, seus corpos se transformam: ali, eles evidenciam outras capacidades e afecções. Uma das transformações mais marcadas é aquela do regime de comunicação. O cotidiano da aldeia é marcado por uma expansividade comunicativa moderada. Há aqui, me parece, algo semelhante ao que diz Gow (1997a) sobre a fala no contexto do parentesco piro. Estes indígenas da Amazônia peruana não falam sobre o incesto, diz o autor, por que ele é " indizível ». Uma relação que retira abruptamente aqueles que nela se engajam do mundo social, transformando-os em uma coisa marcadamente distinta do humano (Coelho de Souza 2004, 2011), não pode ser verbalizada, pois a fala é justamente o meio privilegiado pelo qual uma qualidade central para a socialidade piro e para seu processo do parentesco, o nshinikanchi, «mente, inteligência, memória, respeito, amor », se dá a conhecer. Por outro lado, a fala em excesso vira o processo no sentido contrário, transformando parentes em Outros. " A alegria tumultuária e contagiosa dos rapazes », diz Gow, "faz deles nshinikatu, "descuidados, esquecidiços, sem nshinikanchi”" ", (ibid., p. 50), e é isso que faz seu exagero comunicativo essencial nos funerais, pois age no sentido contrário da memória recíproca que os vivos e o morto ainda têm, 
e que precisa ser rompida (ibid., p. 61, nota 14). É também por uma fala « excessiva» que os homens transformam um outro homem, antes um semelhante, em um diferente: chamando-o por um termo de parentesco para convidá-lo a fazer algo que só um não-parente pode fazer, ele o torna apto a cortar o cordão umbilical de seu filho recém-nascido (ibid., p. 49).

Os Karajá operam uma dinâmica similar. A comunicação intra-humana, por meio de uma língua partilhada, é essencial. Mas a expansividade comunicativa, no convívio cotidiano entre parentes, deve ser moderada - este é o ideal. Não se deve falar demais, nem alto demais, não se deve usar certos vocativos (nomes pessoais, por exemplo) para se chamar determinados parentes, etc. Sem a fala, porém, fica-se privado do principal meio de saber se as pessoas sentem falta uma das outras, se ficam contentes com os cuidados que recebem, de reavivar a memória de acontecimentos co-experienciados, etc. - elementos esses por meio dos quais as pessoas se produzem reciprocamente como parentes. Uma comunicação propriamente humana não permite excessos. Sem a fala, porém, uma humanidade plena, i.e., inỹ, não é possível - por mais que a fala não seja tudo. O luto nos serve, aqui, de exemplo, pois é um período de suspensão da vida humana normal, i.e., da socialidade dos vivos: uma morte interrompe imediatamente a atividade ritual, deixando a aldeia «triste », um estado contrário à alegria que reina durante o ritual; durante o luto, os cuidados com o corpo (corte de cabelo, pintura corporal, etc.) ficam suspensos; e, enquanto ele dura, o silêncio reina - não se pode « cantar, falar alto, gritar, rir, ou demonstrar qualquer atitude de alegria » (Rodrigues 1993, p. 374) - só sendo interrompido pelo choro ritual feminino, ibru (iburu em javaé), uma forma estilizada de discurso que poderíamos caracterizar como « excessiva »: muito alta, bastante prolongada ${ }^{8}$, dotada de uma carga emocional extrema e preenchida com «a acusação nominal e pública dos suspeitos da morte de alguém ${ }^{9}$ » (ibid., p. 72). O luto, em suma, mostra que tanto a escassez de comunicação, o silêncio, quanto seu excesso, o choro ritual, são contrárias a uma socialidade propriamente humana, iny.

Quando os Karajá caminham no mato, à sombra das árvores que se tocam no alto, o silêncio reina. Troca-se a comunicação intra-humana por uma arguta e concentrada busca por sinais visuais e, principalmente, sonoros da presença de outros seres. O assovio dos pássaros, a algazarra de folhas que acompanha a passagem de um bando de macacos, galhos quebrados de uma maneira específica, rastros, grunhidos, esturros e outros sons característicos de animais específicos, frutas comidas, o barulho que um peixe faz na superfície da água, marcas de facão na vegetação, tudo é observado com muita atenção para que se saiba quais são os seres que estão presentes ali, a que distância estão, a quanto tempo passaram no chão que ora se pisa. São sinais das, aos nossos olhos, pouco visíveis interações que estão acontecendo a todo tempo com esses seres, das quais os Karajá têm viva consciência. 
Na aldeia, os corpos estão relaxados. No mato, estão como que num estado de alerta, os músculos quase regados de adrenalina. O corpo não é da mesma forma na aldeia e no mato, porque o corpo só é algo, só existe sob uma forma específica, quando embrenhado num nexo de relações; e se a aldeia é um espaço de socialidade propriamente humana, o mato não o é: ali, se está interagindo a todo tempo com seres outros, e a perspectiva humana, que, diga-se, nunca está garantida, ali está menos ainda. A mudança é visível, mesmo que pouco traduzível na escrita, esse código que só se deixa transpassar pelo sensível muito precariamente.

Mas foi só depois de ter acompanhado os indígenas duas ou três vezes nesta trilha em direção ao Lago do Santana é que me foi feito um comentário que deixou transparecer o sentido desta mudança de afecções corporais (Viveiros de Castro 1996, 2002). Ao longo da caminhada, minhas tentativas de conversar eram sempre malfadadas, justamente por causa desse silêncio, dessa abdicação temporária da comunicação intra-humana. Sempre que eu perguntava algo, as respostas eram curtas, monossilábicas. Às vezes estavam prestando tanta atenção no mato e em seus habitantes, que minha pergunta era sucedida por um silêncio, só quebrado algum tempo depois como um «o que?». Em certo momento, entretanto, um homem se virou para mim (que era o último da fila na trilha) e disse para que eu olhasse, de quando em quando, para trás, pois as onças são silenciosas, nunca se escuta seu caminhar. Caminha-se no mato como uma paca, uma capivara, uma cotia, que, sempre observando os sinais da presença de outros seres, i.e., interagindo com eles, se esquivam na tentativa de não se dar a ver a esse predador que tudo vê, quase onipresente e onisciente, a onça. Ela parece estar sempre escondida atrás de uma árvore ou de um arbusto, não se pode entrar em seu território sem que ela saiba, sem que ela veja. No mato, no território das onças, é-se presa: estar lá é apreender-se sob o ponto de vista delas. A menos que se olhe dentro de seus olhos de resina ${ }^{10}$ e não se demonstre medo, a menos que, temporariamente, se faça do mato uma aldeia.

« Território das onças » é uma expressão em português que serve de tradução para halò hãwa, "a aldeia/território/lugar (hãwa) das onças (halòe) ». Há, porém, outro termo pelo qual se pode referir a um lugar onde é possível encontrar muitas onças (ou outros seres): ho ( $\delta ; h a k u$, o $)^{11}$. Qualquer lugar onde a presença de um ou mais seres determinados se faça notar com frequência pode ser dito um ho. E esses espaços podem ser superpostos. Na Gleba II, por exemplo, há muitas capivaras, antas e peixes, de modo que ali é o ho de todos esses seres, simultaneamente. Se alguém está na aldeia e aponta para essa parte da Terra Indígena e diz kua õri ho, a expressão pode ser traduzida simplesmente como « ali

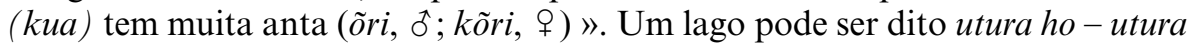
( $\delta ;$ kutura, ) ) são os peixes. Mas qual seria, então, a diferença entre ho e hãwa? Para que um determinado lugar possa ser dito o hawã de um ser, é preciso que ele habite ali. Em relação às onças da Gleba II da Terra Indígena, por exemplo, Kari 
me disse que « elas moram ali, ali é a aldeinha delas ». O sentido dessa expressão ficou mais claro quando, posteriormente, conversando com um homem sobre o assunto, ele me ofereceu a expressão halòe hãwa como tradução para " território das onças" e eu lhe perguntei se havia ali, uma aldeia desse felino. Ele inicialmente me respondeu que sim. Mas quando insisti, perguntando se o hàri (xamã) dava notícias da aldeia das onças, como seria, se tinha casas dispostas como as de uma aldeia inỹ, ele me retrucou que não havia nada disso: quando se fala que " ali é a aldeia delas », é no sentido de que « elas moram ali », de que « ali é o território delas », mas sem a implicação da aldeia no sentido humano, um local muito determinado onde casas são construídas e cujo espaço têm que ser cuidado para que o mato não tome conta, por exemplo.

Os Karajá transitam por muitos lugares no mato, e algumas das características desse trânsito que descrevo aqui, como a relativa ausência de comunicação intra-humana, acontecem, em maior ou menor grau, em todos eles. É importante frisar, entretanto, que, apesar de eu estar usando o termo genérico « mato » para se referir a essa parte da Terra Indígena, a descrição que ofereço aqui se refere apenas ao trânsito pelo território ( hãwa) das onças, e não por outro pedaço de mata qualquer, mesmo que este seja um $h o(\delta, h a k u$, + ) destes felinos.

\section{A aldeia dos brancos}

O que se poderia dizer, então, da relação dos Karajá de Buridina com os tori (os brancos) e sua cidade? Da mesma forma que os Karajá sofrem (ou operam) uma transformação quando estão no território das onças, estar na cidade, que é, afinal, « o território dos brancos » (tori hãwa), também envolve uma dinâmica de alteração. Quando os Karajá vão à cidade, geralmente montados em suas bicicletas, para comprar alimentos em algum dos mercados, pães para seu café da manhã, gasolina ou materiais de pesca, ir ao banco, ou simplesmente quando atravessam um pedaço da cidade no trânsito entre a aldeia (Gleba I) e o Aricá (como chamam a Gleba III), seu corpo também muda, se transforma: na cidade, eles evidenciam outras capacidades e afecções do que quando na aldeia. Assim como no mato, pedala-se em silêncio, como pude igualmente perceber ao acompanhar essas « expedições »: a comunicação intra-humana é colocada de lado em prol de uma arguta e perspicaz observação dos brancos. Observa-se como eles conversam, sobre o que, em que tom e em que situação, como eles fazem seus negócios, o que eles comem, que roupas vestem, como são suas casas, quais são seus trabalhos, o que gostam de fazer no tempo livre, como tratam seus parentes, etc. Assim como no mato, na cidade seus corpos estão sujeitos a uma certa tensão. O relaxamento característico do convívio cotidiano entre parentes na aldeia, onde as pessoas ficam sentadas nas varandas de suas casas, escorados em árvores na beira do rio, conversando entre si, fazendo brincadeiras, etc., é 
substituído por uma certa contenção corporal ${ }^{12}$ : linguística, tanto no sentido já apontado quanto no da comunicação oral com os brancos - tenta-se usar as expressões e formas de tratamento adequadas à gramática do português local e geralmente não se fala mais que o necessário para o fim em questão (pagar as compras feitas, por exemplo) -, e corporal - os movimentos são mais contidos e tem-se a impressão de uma certa dose de cuidado com eles. Essas interações na cidade contrastam marcadamente com as que têm lugar dentro da aldeia - quando, por exemplo, os Karajá recebem visitas de amigos ou conhecidos tori em suas casas -, que se assemelham às relações diárias entre os próprios índios. Se na aldeia a descontração, muscular e dos humores, é predominante, os Karajá, na cidade, estão geralmente sérios: ali não parece ser um local adequado para o riso, por exemplo. Assim como quando caminham no território das onças, ir para a cidade implica apreender-se a si próprio sob a perspectiva dos brancos - os seres para quem aquele espaço é um «território »-, apreender-se como « índio » ${ }^{13}$.

Descrever as idas cotidianas dos Karajá à cidade como uma transformação pode dar uma impressão espetacular para uma situação que é, na verdade, absolutamente ordinária. A transformação é comumente associada a contextos ímpares, espetaculares, como o ritual ou o xamanismo, e pensada como operada por indivíduos em posições determinadas ou com treinamentos específicos. Mas, como lembra Praet (2009, p. 748), falando sobre os Chachi do noroeste do Equador, «transformar-se [shifting shape] não é uma questão apenas de especialistas; na verdade, é algo muito mais comum e menos espetacular do que se poderia pensar » [tradução do autor E.S.N.]. Entre os Matis, por exemplo, basta um grito monossilábico para efetuar uma transformação:

$\mathrm{O}$ que poderia ser imaginado como eminentemente espetacular - homens que se transformam em jaguares - não implica nem tomada de alucinógenos, nem pinturas corporais sofisticadas, nem revestimento com ornamentos marcados pela semântica felina, nem postura, atitude, maneira ou comportamento particularmente evocativos. Um simples monossílabo, reiterado em intervalos regulares durante um tempo relativamente curto (alguns minutos apenas), prosseguindo seu caminho tranqüilamente: a isto se reduzem as metamorfoses matis. (Erikson 2000, p. 43)

Se acima vimos como a relação com as onças, quando se as encontra face a face, pode implicar uma transformação que poderíamos ver como extraordinária, no trânsito cotidiano dos Karajá em direção à cidade, como no simples fato de caminhar no território das onças, trata-se, ao contrário, de algo banal, não-espetacular. Há, porém, outros contextos de transformação, associados às relações com os brancos, que são sim espetaculares e que poderíamos com mais facilidade associar a rituais. Nos casos tratados acima, a transformação é algo quase imperceptível: para percebê-la é preciso, digamos assim, saber ver. Nesses outros contextos que tratarei agora, a transformação, 
como aquelas operadas por máscaras, dá-se a ver: as « máscaras » ${ }^{14}$ em questão são as roupas dos tori. Os Inỹ, nesta como em outras aldeias, há muito abandonaram sua forma própria de «vestimenta ${ }^{15}$ e hoje as roupas dos brancos são tão básicas para eles quanto para nós. Mas há roupas e roupas. Até o começo do período letivo, em fevereiro de 2009, eu não havia - nas curtas estadias anteriores - presenciado a movimentação dos jovens em direção à escola. No primeiro dia de aula, fiquei surpreso ao ver todos muito bem vestidos, com roupas e acessórios que, depois de mais de um mês de campo, eu nem mesmo sabia que existiam (em algumas casas): sobretudo calças jeans e tênis impecavelmente limpos. Esses itens servem exclusivamente a esse fim: ir à escola ${ }^{16}$, e fazê-lo exatamente da maneira como os tori o fazem, como comentou certa vez um homem.

Na verdade, há uma outra situação em que se pode usá-los: sair para « ver o movimento » ou « o frevo », nas noites de festividades, sobretudo, do mês de julho, durante a temporada. O propósito, entretanto, parece ser o mesmo em ambos os casos. A primeira vez com que me deparei com esta situação foi ainda em fevereiro de 2009, durante o carnaval. Numa noite de sábado, eu havia saído para dar uma volta, comer um cachorro quente e, quando eu já estava indo embora, encontrei com Kari e seu marido Curica (tori). Eles estavam vestidos da mesma maneira que qualquer turista, com « roupas de festa » e perfumados. Os calçados mais uma vez me chamaram a atenção: ele calçava um bonito tênis branco e ela um sapato, brilhante e negro, ostentando um curto salto - ambos também impecavelmente limpos. Caminhamos pela rua e subimos pela praça da Igreja Matriz, onde decidiram sentar-se. Enquanto fiquei ali com eles, foi só isso que fizeram: sentados, observavam o movimento, fazendo, eventualmente, alguns comentários.

Algum tempo depois, durante o mês de julho de 2009, acompanhei a família de Renan até a praça Couto de Magalhães, onde, no palco ali armado, assistimos (em dias diferentes) os shows de Elba Ramalho e das bandas Alquimia e Biquini Cavadão. Eles em suas melhores roupas, cruzamos a aldeia rumo ao centro da cidade. Nestes três dias, o roteiro foi basicamente o mesmo: tomar sorvete, andar um pouco, sentar e observar, assistir o show, comer pipoca (ou outra coisa) e voltar para casa. Durante esses passeios, a impressão que se tinha é que as relações internas àquele pequeno grupo indígena davam lugar a uma relação de cada um deles com o ambiente: praticamente não conversavam entre si. Os momentos dos shows foram ainda mais impressionantes, para mim: escutando as músicas, observando os artistas e o público, os corpos dos adultos permaneciam perfeitamente estáticos. As crianças, porém, embora também observassem o movimento, conversavam e brincavam um pouco entre si (mas nada comparado ao ambiente da aldeia). Num desses dias, quando fui ao banheiro público (construído para a temporada turística de 2009), encontrei o cacique Raul Hawakati: com o cabelo preso, ele usava uma camiseta de gola pólo de largas 
listras horizontais, azuis e roxas, cuidadosamente colocada para dentro da calça jeans, onde se afivelava um cinto, preto como os seus sapatos.

Encontramos na literatura Karajá alguns outros relatos sobre essa dicotomia entre as dimensões cotidiana e transformativa da roupa, que certamente soam familiares para pesquisadores e pesquisadoras que trabalham com outros grupos indígenas. Fénelon Costa (1978, p. 31) comenta que « os rapazes de Santa Isabel (e mesmo os homens adultos) usavam no Posto (casa do encarregado e escola, etc.), em 1957 e 1959-1960, apenas um calção, reservando a indumentária completa para irem ao povoado neobrasileiro de São Félix [do Araguaia, Mato Grosso], no outro lado do rio ». Sobre os Karajá de Buridina, dois autores escrevem coisas semelhantes. Baldus (1948, pp. 145-146) diz que « os Karajá tiram a roupa, ou pelo menos parte dela, logo que, chegando em casa, se sentem exclusivamente entre si e fora do contato com os brancos ». Já Wüst (1975, p. 104) fala que « ainda em 1945 não usavam roupa, a não ser quando vinham para a cidade $»$.

O que está em questão nestas situações, acredito, é uma experimentação do ponto de vista dos tori - fazer, como disse, o que eles fazem e, sobretudo, fazê-lo exatamente da mesma maneira que eles. Essas « roupas de festa », poderíamos chamá-las, me parecem poder ser tratadas como dispositivos transformativos comparáveis às máscaras rituais. Usando-as, é-se capaz de acessar um outro ponto de vista. Lembremos que nos mundos do mito e do xamanismo são frequentes as transformações que se operam por roupas: virar onça é vestir uma roupa de onça. Por baixo das « roupas de festa », os Karajá não permanecem intactos, pois a roupa não é uma fantasia, ela não esconde uma humanidade inỹ que se preserva inalterada durante o processo. Como nota Viveiros de Castro (2002, p. 393): «trata-se menos de o corpo ser uma roupa do que de uma roupa ser um corpo. [...] Vestir uma roupa-máscara é menos ocultar uma essência humana sob uma aparência animal que ativar os poderes de um corpo outro » [itálicos do autor V. d. C].

Nessas situações, penso, os Karajá não estão simplesmente " se passando » por turistas, assim como no trânsito cotidiano à cidade eles não estão « se passando » por aruanenses: o que está em questão é uma alteração. Mas há entre essas duas situações uma diferença importante. Se no segundo caso, como disse, eles se apreendem sob o ponto de vista dos não-indígenas, virando índios para estes, no primeiro, eles acessam a perspectiva tori, virando brancos como eles. De fato, mesmo se, de todos os seres que habitam o cosmos do qual os Karajá são parte, os tori são certamente os menos hábeis no jogo da perspectiva, é nessas situações de festa que a grande maioria dos regionais enxerga os indígenas de Buridina como mais iguais a si, i.e., como índios aculturados. A transformação é algo que depende, não só do próprio esforço, mas também da percepção de outros: só se sabe que a transformação foi bem sucedida quando, além de conseguir enxergar o ser outro no qual se transforma como um semelhante, é-se 
visto como um semelhante por ele. Assim, o estereótipo que os regionais nutrem sobre os Karajá - pensando-os como « aculturados », « civilizados » ou « iguais a nós » (cf. Nunes 2012, pp. 246-250) - é uma parte importante do processo, pois, justamente, lhes permite, quando « transformados em brancos », conhecerem-se como semelhantes a eles.

A questão, porém, é mais complexa que a distinção entre «troca de » (apreender-se sob o ponto de vista do Outro ou trocar de posição com ele, i.e., fazê-lo apreender-se sob o ponto de vista do Eu) e « acesso à » perspectiva (ver-se como um semelhante) e a associação dessas duas formas de alteração a dois contextos distintos. Esse quadro me parece, com efeito, majoritário, mas tanto é possível não acessar o ponto de vista dos brancos nas noites de festa, e ser capturado por ele, quanto acessá-lo nas idas cotidianas à cidade. Vejamos, por exemplo, a seguinte fala de Renan Hãburunatu.

Quando a gente vai pra cidade, quando atravessa o portão [da aldeia] ali, tem que tirar a memória indígena, guardar no bolso e colocar a memória de não-índio no lugar [gesticulando com as mãos como se tirasse e colocasse pequenos chips de memória em sua cabeça]. Quando chega pra cumprimentar alguém é « bom dia », " como vão os senhores? », se for uma mulher abraça e dá um beijo no rosto, ou então dá um beijo nas costas da mão. Aí vão saber que quem está ali é um cavalheiro. Porque os índios não se cumprimentam assim, é na distância, não se encostam. Aí quando passa do portão pra dentro tem que tirar a memória do não-índio da cabeça e colocar a memória indígena, que estava guardada [no bolso], no lugar. Aí volta a funcionar do nosso jeito. Então a gente tem que ter essas duas memórias, e as duas são muito importantes pra gente.

Esse jogo depende, em última instância, de habilidades particulares que estão a todo o tempo sob teste. Se uma pessoa logra acessar o ponto de vista dos brancos, no cotidiano ou nas noites de festa, nada garante que outra pessoa também logrará. Nada garante que a mesma pessoa repetirá o feito no dia seguinte, ou duas horas depois, ou na próxima loja que entrar, ou com a próxima pessoa que conversar. O mundo indígena é um mundo sem garantias. E, além do mais, se o que está geralmente em questão no trânsito cotidiano dos Karajá para a cidade é uma troca de perspectiva, apreender-se sobre o ponto de vista dos brancos, isso não é necessário, nem ideal. O ideal, parece-me, é justamente acessar a perspectiva tori - o mesmo, provavelmente, sendo válido no caso das onças. A relação dos indígenas de Buridina com os brancos poderia ser pensada como um análogo do xamanismo, no sentido de que ambos os casos envolvem uma relação longa e intensa como uma forma de alteridade específica que estabiliza a possibilidade de acesso a seu ponto de vista ${ }^{17}$. Mas há xamãs e xamãs. Os mais hábeis nesse jogo conseguem reverter, mesmo nessa situação cotidiana, a assimetria a seu favor: em lugar de ser apreendido pelo ponto de vista de referência, acessá-lo e, assim, afirmar-se como um semelhante frente aqueles seres outros. 
Tendo em vista essas sutilezas no caso das relações com os tori, o que podemos dizer da relação com as onças? Em relação a estas últimas eu disse que os Karajá ora se apreendem sob o ponto de vista delas, quando caminham em seu território, ora trocam de perspectiva com elas, quando as encontram frente a frente e não demonstram medo. Na discussão acima, relativa aos brancos, chamei essas duas formas de relação distintas de troca de perspectiva, pois em nenhum dos dois casos vê-se o Outro como um semelhante. Uma assimetria sempre se mantém: no mato, os Karajá são presas das onças; ou então, olhando-as nos olhos sem demonstrar medo, eles a transformam em presa. Na relação com os não-indígenas, porém, como apontei, há uma outra possibilidade: pode-se ver os tori como semelhantes, é possível tuteá-los, chamá-los pelo pronome de tratamento « tu ». A segunda pessoa, como nota Viveiros de Castro (1996, p. 135) " é o outro tomado como sujeito, cujo ponto de vista serve de eco latente ao do "eu" ". Poderíamos, então, proceder dedutivamente - abrindo, assim, espaço para investigações futuras - e nos perguntar: seria possível, então, encontrarmos, na relação com as onças, uma forma de acesso à perspectiva? E existiria, na relação com os tori, um equivalente do encontro face à face, da troca de olhares, com as onças (Figura 2)?

$\mathrm{O}$ xamanismo é, possivelmente, uma das peças que faltam. $\mathrm{O}$ hàri, o xamã in-ỹ, pode « entrar no corpo » de vários animais, entre eles as onças, passando, assim, a dispor das afecções, disposições e habilidades de seus corpos ${ }^{18}$. Pode até ser que uma onça que porventura se dê a ver no mato seja, de fato, um hàri-onça. Mas não há um xamanismo desenvolvido em Buridina. Práticas xamânicas, como banhos com ervas para finalidades diversas, se fazem ali presentes, e alguns indivíduos possuem conhecimentos sobre tais ervas (os " remédios ») e capacidades xamânicas como, por exemplo, a visão. Não há, entretanto, xamãs reconhecidos e que tenham passado por uma crise iniciatória. Assim, se esse texto apresenta uma certa assimetria em relação aos casos das onças e dos brancos, o segundo aparentemente mais complexo e com mais nuances, isso não se deve a nada intrínseco a uma relação e que falte à outra.

\begin{tabular}{|c|c|c|c|}
\hline \multirow{2}{*}{\begin{tabular}{c}
\multirow{2}{*}{$\begin{array}{c}\text { transformação } \\
\text { em Outro }\end{array}$} \\
\cline { 2 - 3 }
\end{tabular}} & $\begin{array}{c}|c| \\
\begin{array}{c}\text { Eu sob o ponto de } \\
\text { vista do Outro } \\
\text { perspectiva }\end{array}\end{array}$ & $\begin{array}{c}\text { Outro sob o ponto } \\
\text { acesso à } \\
\text { perspectiva }\end{array}$ & \\
\hline $\begin{array}{c}\text { Tori } \\
\text { (brancos) }\end{array}$ & $\begin{array}{c}\text { idas cotidianas do Eu } \\
\text { à cidade }\end{array}$ & shows \\
\hline $\begin{array}{c}\text { Halò̀ } \\
\text { (onças) }\end{array}$ & $\begin{array}{c}\text { Caminhar no território } \\
\text { das onças }\end{array}$ & $\begin{array}{c}\text { Encontro } \\
\text { face àface }\end{array}$ & samanismo) \\
\hline
\end{tabular}

FIG. 2 - Transformações em onça e em branco. 
Uma investigação mais aprofundada sobre xamanismo muito possivelmente complexificaria esse quadro de maneira significativa.

E o que poderíamos dizer sobre o equivalente, na relação com os tori, do encontro face a face com as onças? A peça que falta, aqui, poderia ser a « guerra » com os brancos. Tomemos o exemplo dos Kayapó-Gorotire. Em meio ao processo que Turner (1993, p. 44) chamou de um « desenvolvimento de uma autoconsciência étnica e cultural », esses índios passaram a assumir « o comando da estrutura institucional de dependência »: o chefe de posto da Funai (o órgão indigenista do Estado brasileiro), o operador de rádio, pilotos de barcos e motoristas de caminhão eram todos Kayapó, além de os brancos, como o piloto de avião, serem contratados diretamente pela comunidade (ibid., p. 48). O dinheiro para o pagamento destes funcionários provinha de dois garimpos localizados dentro de suas terras.

Os Gorotire também administram e policiam os garimpos de ouro de Maria Bonita e Cumaruzinho. Neste último, eles mantêm uma força policial de quatro "guerreiros » (como são chamados pelos garimpeiros), que trazem apenas bordunas. Em Maria Bonita, o garimpo maior, eles dispõem de uma força policial idêntica e mais um administrador-chefe, que é também o contador da tribo (ele aprendeu aritmética nas aulas ministradas por dois anos pelos missionários e professoras da Funai). (ibid., pp. 49-50)

Impressionante, nesse caso, é o fato de os Gorotire terem controlado os garimpos, locais onde há geralmente muita violência e tentativas de burlar a fiscalização, quando há alguma, com apenas quatro " guerreiros ». Os indígenas usaram a ferocidade a eles associada a seu favor. Assim, não seria o controle policial desses sítios pelos Kayapó-Gorotire - uma forma de « guerra » com os brancos - uma maneira de capturar os garimpeiros em seu próprio ponto de vista e, dessa forma, fazê-los se apreender não como " garimpeiros em área indígena », mas como « garimpeiros em área indígena »? O enfretamento dos regionais pelos Karajá de Buridina para a demarcação e desocupação da Terra Indígena parece ter colocado em cena essa possibilidade. As Glebas II e III foram desocupadas a partir de iniciativa dos Karajá ( $c f$. Nunes 2009, 2012). Quando um jovem indígena cumpriu a ameaça da comunidade e matou uma rês dos posseiros da Gleba II, estes viram que a ameaça era real e desocuparam a área sem oferecer resistência. Não teria sido essa ação da comunidade uma forma de fazer com que esses brancos se apreendessem sob o ponto de vista dos Karajá, vendo-se não como « camponeses » ou « ribeirinhos », mas sim como « invasores »? Algum tempo depois, a desintrusão da Gleba III também se seguiu a uma iniciativa da comunidade. O dono da fazenda Aricá se recusava a sair da área, fazendo ameaças aos indígenas. Aproveitando uma viagem do fazendeiro, um grupo de jovens homens karajá invadiram a sede, fazendo, assim, com que a Polícia Federal fosse até o local e a área fosse desocupada. Também aqui, não teria sido 
esse enfrentamento por parte dos indígenas uma forma de fazer com que esse tori se apreendesse sob o ponto de vista dos Karajá, vendo-se não como um « fazendeiro », mas sim como um « posseiro » ou « invasor »?

\section{HaWA: LUGAR E PERSPECTIVA}

Passeamos até agora pelo «território das onças» e pela «aldeia dos brancos », mas não pela aldeia indígena. O termo da língua indígena para aldeia é hãwa. Essa palavra, entretanto, guarda uma polissemia, sendo traduzida pelos Karajá ora por « aldeia », ora por « lugar onde se situa/constrói uma aldeia », ora simplesmente como "lugar». Esse conceito se refere, de fato, a uma configuração espacial que abarca esses três significados, e que os Karajá costumam definir em português como território. "Hãwa é tanto uma "aldeia" quanto um território definido ao redor de uma aldeia » (Rodrigues 2008, p. 247, nota 7), que inclui um trecho do rio, pontos de caça, pesca e coleta e uma área cultivável, basicamente.

Se as aldeias inỹ são inỹ hãwa, as cidades dos brancos são tori hãwa, «aldeia/território/lugar dos brancos » ${ }^{19}$. Quando os Karajá se referem ao « território das onças », vimos acima, eles estão também se referindo ao conceito de hãwa. Assim, as três perspectivas tratadas aqui, a dos indígenas, a das onças e a dos brancos, estão ancoradas em três lugares específicos, respectivamente: iny hãwa, tori hãwa e halòè hãwa. Para os Karajá, sua aldeia ou seu «território » se opõe aos desses outros seres. Mas há ainda um outro tipo de lugar que poderíamos inserir nesse quadro: as praias. Os Inỹ costumavam se dispersar, divididos em pequenos grupos familiares, pelas praias de areia branca que emergiam com a baixa das águas. Nas praias realizavam-se, inclusive, rituais ${ }^{20}$. Elas, portanto, são também um espaço de socialidade inỹ. Isso pode ser visto facilmente. Assim como na aldeia, quando na praia, os corpos estão relaxados, as pessoas conversam descontraidamente entre si, brincam, fazem piadas, etc.: em ambos os lugares, seus corpos são do mesmo modo. Um acampamento sobre a areia é, com efeito, uma pequena aldeia, com casas - as barracas de acampamento - geralmente « habitadas » apenas por parentes próximos, um « terreiro » onde as pessoas se reúnem para conversar e um fogo no qual a comida é preparada - onde uma mulher prepara a comida para seu marido. O mesmo pode ser dito de quando os Karajá estão sobre o rio, em suas canoas: seus corpos aí, são como quando na aldeia. Os Inỹ são um povo ribeirinho, « o pessoal do rio » (berohokỹ mahãdu, os Karajá, e berobiowa mahãdu, os Javaé), mas não apenas por viverem à beira do Araguaia (e do Javaés) e por tirarem das águas parte importante de seu sustento: o rio é também um espaço de vida inỹ, uma extensão da aldeia, por assim dizer (ao menos o trecho que faz parte do território da aldeia). 
Se a aldeia, o rio, e as praias são lugares propriamente humanos e que, portanto, propiciam uma socialidade propriamente humana, os dois outros, o " dos brancos e das onças, são territórios de seres outros, e o que está em questão neles é a alteração. Os hawã, com efeito, parecem se constituir como um locus de estabilização das perspectivas dos seres para quem eles são um lugar, uma aldeia, um território. Me deparei com esse idéia ao conversar com um homem sobre a situação da aldeia Itxalà, cuja população é praticamente toda fruto de casamentos entre Karajá e Tapirapé. Perguntei a ele, provocativamente: se aqueles indígenas eram todos misturados (como eles dizem) de Karajá e Tapirapé, porque eles seriam Karajá e não Tapirapé? Ele respondeu prontamente que eram Karajá porque continuavam morando em uma aldeia karajá. Se eles tivessem ido morar em Urubu Branco, um antigo sítio para o qual os Tapirapé retornaram após viver anos com as Karajá, eles seriam (se tornariam) Tapirapé. Essa fala deve soar familiar para muitos etnólogos e etnólogas. Afinal, habitar uma aldeia construída de modo apropriado é comumente um dos elementos definidores da humanidade da pessoa. Esse é o caso dos grupos Jê, em cujas aldeias « é o próprio discurso sociológico que se inscreve e se deixa ler sobre o solo [...]. A todo princípio de organização social é designado um lugar, um espaço, nesse esquema sociológico » (Carneiro da Cunha 1993, p. 85 [tradução do autor E.S.N.]). Sobre os Krahó, Mellati (2005 [1967], p. 75) diz que, « de um modo geral, aqueles que, seja qual for seu aspecto físico, habitem nas aldeias circulares, tomando parte nas atividades rituais, são considerados índios » ( $c f$. também Nimuendaju 1946, p. 85). No caso de alguns grupos, seus próprios termos de autodesignação fazem referência a seu local de habitação: o grupo conhecido na literatura como Suyá, por exemplo, se autodenomina mekïsêdjê, « povo das grandes aldeias circulares » (Seeger 1981, p. 67) ${ }^{21}$. Os lugares, com efeito, e mais especificamente aqueles em que se habita, as aldeias, são mais do que um substrato físico sobre o qual as pessoas vivem: eles participam do processo de constituição recíproca das pessoas como propriamente humanas. Vejamos como isso se dá entre os Inỹ.

Uma das maneiras pelas quais os Inỹ podem determinar o pertencimento territorial de uma pessoa, sua « origem », como dizem, está relacionada com os lugares: uma pessoa pode ser dita original de uma aldeia porque foi criada ali, e, assim, guarda muitas «memórias espacializadas » de atividades e eventos que dividiu com seus parentes - lembranças de pescar com o pai, avô ou tio em um lago específico, de ver a mãe ou avó assando uma boneca de cerâmica nos fundos da casa, etc. Essas memórias, poderíamos dizer, " estão » nos lugares, eles as retêm. Ao passar por um local específico - um determinado lago em que se costumava pescar com o pai, uma árvore plantada pela avó, o antigo local de moradia de um tio, uma beira de lago onde se fazia roça -, as pessoas rememoram a história desse lugar, sempre ligada a vínculos de parentesco (com efeito, são os próprios lugares que parecem suscitar essas lembranças); e essa é frequentemente 
a ocasião em que os mais velhos contam narrativas - sobre seus parentes falecidos, sobre como era aquele lugar quando se era criança, sobre o que se costumava fazer na juventude, etc.

Os lugares, com efeito, participam do processo de produção de parentes: uma roça que um homem planta e que produz alimentos que sua esposa cozinha, uma casa que ele constrói e que sua esposa limpa, os lagos e trechos do rio onde ele pesca os peixes e tartarugas que sua esposa preparará, por meio desses lugares, os cônjuges se dão a lembrar uns para os outros e, assim, produzem-se como parentes; também por meio dessas lembranças recíprocas e especializadas, eles propiciam os fluxos de alimentos, afetos, cuidados, palavras, etc. que produzirão seus filhos como pessoas propriamente humanas, in $\tilde{y}^{22}$. E isso também retroativamente: um homem sabe reconhecer um bom ponto para pescar tartarugas, por exemplo, muito possivelmente porque, quando ainda era um rapaz, ele saiu para pescar com seu pai, tio ou avô em locais que este havia escolhido como propício; esse homem mais velho, por seu turno, saiu para pescar porque precisava « colocar comida em casa » ${ }^{23}$. A implicação dos mais jovens nesses lugares, assim como a implicação do ouvinte piro de uma narrativa que fala sobre lugares e pessoas, " ocorre por meio da agência das pessoas mais velhas » (Gow 1997b, p. 51). A ligação que as pessoas assim estabelecem com seus « locais de origem »- a aldeia no sentido amplo de hãwa, que inclui não só o aglomerado das casas como também o território a seu redor - é tão forte que mudar de aldeia é um processo quase traumático. "One's village is the focus of considerable value for the Karajá. There is a feeling of homesickness when away, and never does a Karajá become comfortable in another village " (Donahue 1982, p. 174). E isso está certamente relacionado com uma forte preferência pela endogamia de aldeia ( $c f$. Rodrigues 2008, p. 738; Donahue ibid., p. 145; Lima Filho 1994, p. 134).

Os grupos domésticos inỹ são concebidos como grupos de descendência matrilinear espacialmente localizados ${ }^{24}$. A interpretação original que Patrícia Rodrigues oferece para essa « filiação matrilinear à casa » é bastante sugestiva para a questão que ora nos ocupa. A descendência na América do Sul indígena, sabemos há algum tempo, não é uma relação de tipo jural. Não se trata, aqui, da transmissão de direitos e bens: os grupos corporados ameríndios são, antes, grupos corporais (Seeger, DaMatta e Viveiros de Castro 1979; Seeger 1980). Rodrigues argumenta que, para os Javaé, a descendência, mesmo se formulada em termos de uma conexão de substância para com maternos e paternos - no caso da casa, uma ligação com os parentes matrilineares por meio de « influências menos visíveis das substâncias maternas » (2008, p. 521) -, não pode ser separada da residência, respondendo a uma espacialização da sociedade (ibid., p. 548).

Os ancestrais de alguém são referidos como os seus lahina, palavra que contém um componente espacial, ao invés de genealógico, expresso através do sufixo $n a$. Literalmente falando, lahina significa « o lugar (na) da avó (lahi) », indicando que os 
ancestrais não são um grupo de quem se descende pela via matrilinear, mas um grupo de pessoas que se define pela co-residência em um determinado espaço, associado principalmente à figura das avós ancestrais. (ibid., p. 556 [itálicos do autor E.S.N.]).

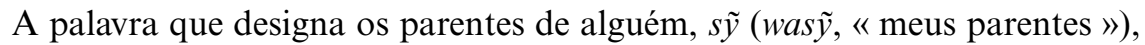
tem também uma acepção mais ampla de « abrigo », podendo referir-se tanto à «casa » (heto, ơ; hetoku, + , o termo mais comumente traduzido por casa, se refere ao aspecto físico da construção) quanto à «aldeia » (o hãwa de que estamos falando): uma pessoa, portanto, pode se referir à sua própria aldeia como « os meus parentes ». Nas palavras de Toral (1992, p. 57), « os Karajá usam uma só palavra [wasy, sic] para se referirem à idéia de "meu lugar" e "minha família"».

Como a literatura recente tem apontado, as paisagens ou os lugares não são meras «construções sociais » ou « culturais », no sentido de uma camada de significação adicionada sobre um substrato material bruto, dado, o espaço ( $c f$. Hirsch 1997; Casey 1996; Ingold 2000). A paisagem da floresta amazônica, por exemplo, diz Gow (1997b, p. 44), não é « observada de fora » pelos Piro, eles não a representam, no sentido de uma construção, como um mapa, que « stands for something else in its absence ». Os Piro estão implicados nessa paisagem, sua terra: as atividades que o parentesco propicia, como a pesca, a caça e o plantio (roças de coivara) constituem a floresta; as almas dos mortos ficam presas a lugares específicos, que os vivos evitam; os olhos do xamã podem ver a floresta como espaço habitado por uma pluralidade de Outros « humanos ». Os Piro conhecem sua terra e a transformam não porque a « observam » ou a « representam », mas porque estão implicados em relações de parentesco uns com os outros e em relações com vários seres outros, como os mortos e os « demônios dos ossos » (ibid.). O conhecimento desses lugares, portanto, só pode ser transmitido por narrativas se os ouvintes já estão implicados nessa paisagem - e o próprio ato de narrar e ouvir as histórias depende da implicação recíproca (relações de parentesco) entre o narrador e o(s) ouvinte(s). Por isso as narrativas Piro tem uma imprecisão na localização dos acontecimentos. Quando Gow perguntava «onde exatamente você estava vivendo quando isso aconteceu? ", a resposta dos Piro era « um vago "ali" ou "descendo" o rio, logo depois de onde o velho Julio Felipe vai fazer sua nova roça' » (ibid., p. 51). É apenas quando as pessoas sabem onde esse « ali » ou a nova roça de Julio Felipe ficam que a narrativa adquire seu sentido. "Se você não sabe, como isso poderia fazer diferença? » (ibid.). Como diz Casey (1996, p. 18), « não há como conhecer ou sentir um lugar exceto estando naquele lugar, e estar em um lugar é estar em uma posição para percebê-lo » (cf. também Ingold 2000). Os lugares, prossegue Casey, são eles próprios constituídos pelo engajamento das pessoas ( « corpos vividos ») com eles. Esse é certamente o caso de uma aldeia inỹ. 
A aldeia é o lugar onde a vida humana acontece. Por isso, é necessário cuidar dela, não deixar, por exemplo, que o mato tome conta. Os quintais e pátios das casas são constantemente limpos, o mato é cortado, as folhas que caem das árvores são rasteladas, o lixo é varrido e acumulado em um canto, e periodicamente queimado. Nas ruas (que passam na frente das fileiras de casas) e trilhas (que ligam uma fileira à outra) da aldeia, o mato não cresce, porque pessoas (bicicletas e veículos) estão constantemente transitando nelas. Assim, a forma da aldeia, com suas ruas e trilhas, existe mesmo em função da movimentação das pessoas para dentro e para fora da aldeia e entre os grupos domésticos. E também porque casas foram construídas em posições específicas umas em relação às outras. Casais novos saem da casa de seus pais/sogros, onde residem após o casamento, e constroem casas para si, geralmente próximas à casa do casal sênior ${ }^{25}$. As construções também envelhecem e, assim, precisam ser periodicamente reformadas. Para que sejam locais propícios para se viver, elas têm que ser constantemente limpas. As árvores que se erguem à beira do barranco, características das aldeias inỹ, foram plantadas por seus habitantes. Algumas delas perduram por gerações. E tudo isso, é claro, traz a marca do parentesco. Uma aldeia existe sob uma forma adequada devido aos trabalhos recíprocos dos cônjuges, ao trabalho dispensado por eles para criar seus filhos, às visitas que os parentes fazem uns para os outros, etc. É a socialidade inỹ, em suma, que constitui o espaço da aldeia. Ao mesmo tempo, porém, ela é constituída por esse espaço. Em um sentido, são as casas que fazem com que as pessoas morem juntas, dividam o mesmo espaço; são os pátios que reúnem os parentes nos fins de tarde; são os caminhos que conduzem as pessoas para dentro e para fora da aldeia e de sua casa para a casa de seus parentes; e, como disse acima, os lugares retém memórias e, assim, dão os parentes a se lembrar uns dos outros.

$\mathrm{Se}$, portanto, engajamento recíproco de pessoas e lugares constitui a ambos (cf. Casey, ibid.), a ligação (afetiva, emocional) que se estabelece com o espaço da aldeia por meio da residência é mais do que metafórica. Ele me parece conferir, enfim, um embasamento etnográfico ameríndio para a passagem de Lévy-Bruhl (1922) que serve de epígrafe a este texto: participando uns dos outros, pessoas e lugares entretêm uma relação metonímica. Isso se expressa em outra forma de legitimar o direito de pertencimento a um lugar, a " origem » de alguém, como dizem: uma pessoal « é original » do lugar onde sua placenta ( saa) foi enterrada. Rodrigues (2008, p. 558) diz que uma das expressões pelas quais os Javaé se referem a esse direito é wasaabòròna, « literalmente "o lugar (na) das costas (bòrò) na minha placenta (wasaa)", que metaforicamente é "o lugar onde se enterrou ou tampou a minha placenta" ». Os Karajá mais velhos de Buridina dizem que a placenta era enterrada no mato, nas proximidades da aldeia (cf. também Donahue 1982, p. 113; Aytai 1979, p. 6; Krause 1943, p. 201). Dizem que era costume que a mãe guardasse a parte do cordão umbilical que fica colado à barriga da criança (binõti) depois que ele secava e se descolava do bebê até que 
seu filho tivesse idade suficiente para memorizar os acontecimentos. Então, ela mostrava o umbigo ${ }^{26}$ ao filho para depois enterrá-lo junto à placenta e ao cordão (cf. também Donahue ibid., pp. 113-114). Dizem ainda que « o umbigo chama »: uma pessoa pode andar muito, mudar várias vezes de aldeia, mas acaba escutando a esse chamado e voltando para o lugar onde seu umbigo foi enterrado. Não posso dizer muito sobre a placenta, que, entre outros grupos ameríndios, é um « duplo » ou « o companheiro » da criança, um Outro (cf. Gow 1997a). Mas quando perguntei a um homem se, mesmo depois de enterrado, o umbigo continuava fazendo parte da pessoa, ele me respondeu que $\operatorname{sim}^{27}$. Assim, talvez seja possível dar ainda um passo além e dizer que os lugares não apenas participam do processo de aparentamento entre as pessoas, mas que é possível se aparentar com os lugares, produzir relações para com eles. Talvez, da mesma forma que os parentes (humanos) assemelham seus corpos por meio do fluxo de palavras, cuidados, substâncias corporais, alimentos, etc., as pessoas se assemelhem a seus lugares de origem: os umbigos são enterrados nas proximidades da aldeia, as pessoas cospem no chão, caminham sobre ele, contam histórias sobre ele, sentadas em cadeiras apoiadas nele; as casas " cuidam » (abrigam) das pessoas, os pátios convidam as pessoas a se sentarem, as árvores bloqueiam o sol para que as pessoas não sintam tanto calor. Talvez também assim os lugares se constituam como partes das pessoas.

Mas voltemos ao hãwa. Cada território, hãwa, é a aldeia de alguém e, assim, ele constitui, ao mesmo tempo em que é constituído por, seus habitantes. E se cada lugar tem seus moradores, a maneira de estar ali depende da relação que se estabelece com eles ( $c f$. Coelho de Souza 2009, p. 30). O trânsito entre diferentes lugares (aldeias, territórios), portanto, implica se relacionar com a perspectiva dos seres outros que os habitam. Além do mais, Rodrigues (2008, p. 550) demonstra que o próprio movimento, para os Javaé, está ligado à transformação. É por meio do movimento, uma longa caminhada desde as cabeceiras até a foz do Araguaia, que o demiurgo Tanỹxiwè (Kànỹxiwè, para os Karajá) « deixa a condição de corpo fechado, no início do rio, para tornar-se um pai de corpo aberto quando chega ao fim, onde se encontra com o filho já crescido ». É também por meio do movimento, a mudança de residência implicada pela uxorilocalidade, que os homens abrem seus corpos, produzindo filhos, possibilitando assim a continuidade da vida inỹ. Por mais que a autora confira à « transformação » um sentido bastante preciso, que não cabe explorar aqui, a idéia não deixa de ser produtiva. Esse deslocamento espacial após o casamento não implica, para o homem, também uma mudança de perspectiva? Se na casa da mãe é-se um filho, um semelhante, na casa dos sogros é-se um genro, um diferente ${ }^{28}$ : o que se é na casa da esposa depende das relações que se trava com seus habitantes, os afins.

Se a humanidade tem que ser continuamente produzida, se ela nunca está garantida, se, em suma, os corpos são cronicamente instáveis (Vilaça 2005), e se 
a relação das pessoas com seus lugares de moradia é metonímica, os lugares ( hãwa) estabilizam a perspectiva dos seres seus habitantes. A relação que se estabelece com os «territórios » de seres outros, assim, é, antes de tudo, uma relação com o ponto de vista desses seres. Mesmo se há formas múltiplas de relação, desenvolvidas ao longo de um duradouro histórico de interações, como tentei apontar, a forma básica de se estar num território outro é apreender a si próprio sob a perspectiva de seus moradores, aqueles para os quais tal espaço é um hãwa. O trânsito dos Karajá de Buridina entre sua aldeia, a cidade e o mato é, portanto, um intricado jogo de pontos de vista.

\section{Nota Final}

As descrições que fiz aqui das transformações que caminhar no território das onças ou transitar na cidade implicam para os Karajá são, certamente, muito sumárias. E isso foi, pelo menos até certo ponto, proposital. Pretendi mais apontar que os corpos indígenas dispõem diferentes afecções e capacidades na aldeia, no mato e na cidade, e menos descrever detalhadamente essas diferenças. É claro que uma série de informações adicionais - sobre a forma inỹ do processo do parentesco, sobre a dinâmica de constituição dos grupos domésticos (e sua relação com a morfologia da aldeia), sobre os componentes da pessoa (alma, sangue) e sua relação com a produção de pessoas humanas, inỹ, etc.; assuntos esses que desenvolvi em mais detalhes em minha dissertação (Nunes 2012) tornariam o argumento mais sólido. Porém, se optei por fazer descrições mais breves, foi pelo benefício da comparação entre as relações com dois tipos de seres outros (as onças e os brancos) que são comumente tratadas em separado - como remetendo a esferas distintas, esferas de análise e, por vezes mesmo esferas da vida indígena. Um dos objetivos desse artigo, embora tangencial, é apontar para a produtividade de se utilizar um mesmo quadro de análise para tratar tanto das relações com os brancos como das relações com outras figuras da alteridade. Se, para os índios, os brancos são Outros, figuras da alteridade, vale considerar mais detidamente a possibilidade de comunicação entre as relações com seres tão distintos quanto as onças e os brancos. Nesse texto, tentei mostrar que, embora haja diferenças - sempre as há -, os trânsitos dos Karajá no mato e na cidade colocam em cena processos análogos.

Outro ponto importante é que, como disse no início, esse artigo é uma reflexão sobre as transformações que esses trânsitos por territórios outros suscitam nos Karajá. Os índios, entretanto, dificilmente explicitam verbalmente essas mudanças de afecções, disposições e capacidades corporais, no que tange especificamente às idas à cidade e ao mato. Entretanto, no que se refere a outros aspectos das relações com os brancos - o uso de uma série de utensílios não-indígenas (luz elétrica, gasolina, redes de pesca de nylon, ferramentas 
diversas, etc.), falar o português (ao lado da língua karajá), usar roupas industrializadas cotidianamente ou comer «comida tori», por exemplo -, é comum ouvir asserções mais explícitas quanto a "virar branco »; o que torna possível perceber como os Karajá entendem a transformação. Desenvolvi esse ponto em outro lugar (Nunes 2012, cap. 6). Nesse texto, porém, minha abordagem foi fenomenológica: tentei descrever mudanças de afecções, capacidades e disposições corporais que, embora por vezes pouco perceptíveis, são bastante concretas, do ponto de vista do engajamento dos corpos karajá tanto com o mato quanto com a cidade e com os habitantes desses diferentes hãwa. *»

* Manuscrit reçu en octobre 2012, accepté pour publication en mai 2013.

\section{Notas}

Este artigo é uma versão compactada de um capítulo de minha dissertação (Nunes 2012). Agradeço à leitura atenta e aos comentários de Marcela Coelho de Souza, Fabiano Bechelany, Guilherme José da Silva e Sá e Luis Cayón. Agradeço também a gentil ajuda lingüística de Oiara Bonilla.

1. «Inỹ » é o termo de auto-designação dos Karajá, Javaé e Xambioá; rybè significa «fala », « língua », «modo de falar». Essa língua apresenta uma diferenciação da fala segundo o sexo do falante, geralmente caracterizada pela queda, na variante masculina, de uma consoante (majoritariamente a oclusiva velar surda $/ \mathrm{k} /$ ), localizada entre duas vogais ou no início de palavras da fala feminina (Ribeiro 2012, cap. III). As formas masculina e feminina das palavras são indicadas

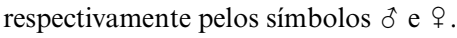

2. Para mais detalhes sobre a situação espacial da aldeia e informações sobre história da aldeia e da cidade (Nunes 2009, 2012).

3. Os Karajá distinguem três tipos de onça: a onça pintada, a onça preta e a onça vermelha. Para a biologia, as duas primeiras são uma única espécie, « Panthera onca ». Quarto maior felino do mundo, é o maior das Américas, possui corpo largo e musculoso e cauda curta. Pesa em média $61.4 \mathrm{~kg}$ (de $35 \mathrm{~kg}$ a $130.5 \mathrm{~kg}$ ), com um comprimento médio de corpo de $1.32 \mathrm{~m}$ (de $1.10 \mathrm{~m}$ a $1.75 \mathrm{~m}$ ) e de cauda de $57.6 \mathrm{~cm}$ (de $40 \mathrm{~cm}$ a $68 \mathrm{~cm}$ ). É encontrada das planícies costeiras do México até o norte da Argentina, em toda a Amazônia até o leste do Maranhão, Brasil central, e pantanal. A onça vermelha, mais conhecida alhures como onça parda, espécie « Puma concolor », é o segundo maior felino do Brasil. Possui corpo grande, cauda longa e cor uniforme. Pesa em média $39.2 \mathrm{~kg}$ (de $22.7 \mathrm{~kg}$ a $73.8 \mathrm{~kg}$ ), com um comprimento médio de corpo (cabeça + corpo) de $1.08 \mathrm{~m}$ (de $0.9 \mathrm{~m}$ a $1.53 \mathrm{~m}$ ) e de cauda de $61.5 \mathrm{~cm}$ (de $46.9 \mathrm{~cm}$ a $81.5 \mathrm{~cm}$ ). É encontrada numa área mais extensa que a onça pintada, do oeste do Canadá ao extremo sul da América do Sul e praticamente em todo território brasileiro (Oliveira e Cassaro 1999, pp. 41-46). Os Karajá, por seu turno, distinguem a onça pintada, halòè ou halòè ràti, considerada como a maior das três, da onça preta, halòe lyby, reservando para a onça vermelha os termos obryra

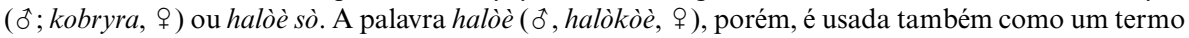
genérico para qualquer tipo de onça.

4. $\mathrm{O}$ « esturro » é um som grave que as onças emitem, uma espécie de roncado - mas não se trata de seu rugido.

5. Quando a onça está com filhotes pequenos, ou como dizem os Karajá, quando ela está « parida », ela é muito mais perigosa do que normalmente, podendo atacar e matar sua presa mesmo que não a deseje comer, abandonando o cadáver no mato.

6. Ao falar da posição de sujeito(-predador), faço aqui referência à formulação de Viveiros de Castro (1996, p. 126) do perspectivismo ameríndio. Diz o autor: « todo ser a que se atribui um ponto de 
vista será assim sujeito [...]; ou melhor, ali onde estiver o ponto de vista, também estará a posição de sujeito. Enquanto nossa cosmologia construcionista pode ser resumida na fórmula saussureana: $o$ ponto de vista cria o objeto - o sujeito sendo a condição originária fixa de onde emana o ponto de vista -, o perspectivismo ameríndio procede segundo o princípio de que o ponto de vista cria o sujeito; será sujeito quem se encontrar ativado ou "agenciado" pelo ponto de vista » [itálicos do autor E.S.N.]. A posição de objeto(-vítima), assim, é uma extensão dessa idéia.

7. Lévi-Strauss (1976) há muito nos ensinou que a mitologia não opera com as coisas do mundo necessariamente como elas são: ora ela as reproduz, narrando-as como de fato são na vida indígena, ora ela as espelha, produzindo uma imagem invertida. A mitologia Karajá sobre as onças é um exemplo claro disso: predador voraz, prototípico, no mundo da vida, a onça é um benevolente quase bobalhão no mundo do mito. Personagem que sempre se presta ao diálogo e a ajudar os protagonistas das narrativas, a onça mítica Karajá é sempre enganada, feita de bobo, por outras personagens: tem sua cabeça amassada pelo tracajá ( $c f$. Pimentel da Silva e Rocha [2006, pp. 156-157] para uma versão publicada desse mito), se deixa amarrar e serve de montaria ao coelho, perde seus olhos por sua ingenuidade de não perceber as artimanhas do tamanduá ( $c f$. nota 10).

8. « Nos primeiros dias após a morte, há um número maior de mulheres chorando, cada uma em sua casa, por toda a aldeia, o que vai decrescendo com o passar dos dias. A voz das mulheres, intensa e forte no começo, vai enfraquecendo e, alguns dias depois, ouve-se apenas fios de vozes insistentes, mulheres completamente roucas e quase afônicas, mas que persistem em chorar pelo morto " (Rodrigues 1993, p. 370).

9. E continua a autora, em uma formulação também válida para os Karajá: « falar o nome de alguém em público, em tom de acusação, é considerado grave pelos Javaé. Só as mulheres, durante o luto, podem fazer isso, sem que lhes aconteça nada» (ibid., p. 372).

10. Duplamente enganada pelo tamanduá bandeira, a onça joga seus olhos para o alto, na segunda prova ardilosa proposta pelo seu opositor, e os perde, substituindo-os depois por outro par feito de resina, narra um mito Karajá. Esse tema é comum na mitologia sul-americana (cf. Lévi-Strauss 1964), mas é mais frequentemente de água que os novos olhos da onça são feitos.

11. Haku é a forma da fala feminina para ho, na fala dos homens. A despeito de parecerem duas palavras distintas, a segunda pode ser derivada da primeira por meio de processos fonológicos regulares: quando a queda do $/ \mathrm{k} /$ na fala masculina provoca o encontro vocálico entre $/ \mathrm{a} / \mathrm{e} / \mathrm{u} /$, as vogais se fundem dando origem a um /o/. O mesmo processo ocorre em outras palavras, como bèraku, na fala feminina, ou bero [bèrau > bero], na fala masculina, « rio » (cf. Ribeiro 2012, cap. III).

12. A vida diária na aldeia, é claro, também tem suas tensões; quando falo do relaxamento característico desse ambiente me refiro à sociabilidade, ao convívio pacífico, entre parentes, e não, por exemplo, às querelas que ocorrem entre parentelas - essas são também constitutivas da socialidade in-ỹ, mas tem um caráter mais incidental.

13. Refiro-me a imagem do « índio » tal como ela aparece no imaginário popular.

14. Se eu estiver certo quanto à intuição de que os ijasò, os Aruanãs que vão dançar nas aldeias durante o Hetohokỹ (ritual de iniciação masculina) e as festas de Aruanã, são seres Outros, se, a despeito de serem os ancestrais dos Karajá, eles não são os « humanos originais » mas sim os « Outros originais », o ritual inỹ nos fornece um exemplo de transformações efetuadas por máscaras: os dançarinos vestem máscaras de palha, que são réplicas dos corpos dos ijasò, tal como observados pelo hàri (xamã) em suas visitas aos mundos desses seres, e, ao fazerem isto, transformam-se eles mesmo nos Aruanãs - vestir a máscara é, também, vestir a pele velha [tyytàby, ớ; tàkytàby, †] do Aruanã (justamente a parte de sua pessoa-corpo trazida pelo xamã à aldeia). Um homem me descreveu, certa vez, a atividade dos xamãs por meio da expressão hàri rityytàbynỹmỹhỹre, que poderia ser traduzida aproximativamente por « o xamã confere alma »: tyytàby é um componente imaterial da pessoa que poderíamos, grosso modo, traduzir como "alma », e -nỹ é um verbalizador, de modo que o nome verbalizado rityytàbynỹ significa, aproximadamente, a ação de "conferir alma "; -mỹhỹ é um continuativo, que, associado à posposição -re, um imperfectivo, indica que se trata de uma ação ou atividade usual, algo que se faz com certa regularidade. Lourenço $(2009$, p. 108) diz que « no ritual, os 
Aruanãs ocupam os corpos dos dançarinos ou como me explicaram (nos bastidores), que os homens usam o tykytyby dos Aruanãs para dançar e cantar ». Esse, porém, é um tema pouco explorado na literatura in-ỹ, e uma pesquisa mais aprofundada sobre o assunto seria fundamental para levar adiante a reflexão sobre como os Karajá entendem a transformação e para desenvolver a analogia entre as « roupas de festa » e as máscaras rituais.

15. No caso dos homens, uma forma de « estojo peniano » que consistia em amarrar a pele do pênis com um cordão de algodão untado de urucum, de modo a esconder a glande. No caso das mulheres, uma tanga de entrecasca chamada inỹtu, « couro (tu) de gente (inỹ) ».

16. Aqui faço referência ao Colégio Estadual Dom Cândido Penso, localizado fora da aldeia (apesar de dentro da Glaba I da Terra Indígena). Quando se trata de ir ao Colégio Maurehi, a escola indígena localizada dentro da aldeia, nunca vi esforço comparável de se vestir ao modo tori - a indumentária é bem próxima da cotidiana.

17. Sobre a comunicabilidade entre as relações com os brancos e o xamanismo, $c f$. Vilaça (2000, 2007), para o caso Wari', e Kelly (2011), para o caso Yanomami.

18. Não há referência, na literatura específica, sobre se essa capacidade xamânica de entrar no corpo de outros seres implica uma mudança de perspectiva; que, por exemplo, ao entrar no corpo de uma onça, o hàri veja o mundo com os olhos do felino. Entretanto, é a essa conclusão que meu material etnográfico me conduz, tanto no que diz respeito às onças quanto em relação a outros seres, como o pirarucu (Arapaima gigas) que frequentemente servem de abrigo às peles velhas ou « almas » alheias ( $c f$. por exemplo, M5(2) em Nunes 2012, p. 377). Ainda sim, seria necessária uma pesquisa mais densa para sustentar o ponto, a colocação do xamanismo nesse lugar de meu quadro, portanto, tendo um caráter mais especulativo que conclusivo.

19. Esta informação está também presente nas etnografias de Donahue (1982, p. 172) e de Bonilla (1997, p. 81). Outro termo para cidade, e que, ao menos em Buridina, é raramente usado, é hãwahakỹ,

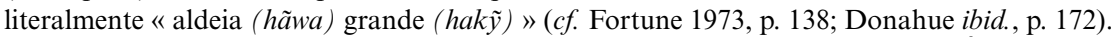

20. Essa dispersão pelas praias do Araguaia, é claro, ocorria na época da seca. À medida que o rio ia baixando mais e mais, as famílias iam mudando de acampamento, entrando pelos afluentes, indo para as beiras de lagos, sempre à procura dos pontos de maior fartura. Quando caiam as primeiras chuvas, as famílias iam regressando, até se concentrarem novamente na aldeia, época na qual se realizavam (e ainda se realizam) os grandes rituais coletivos, sobretudo o Hetohokỹ (iniciação masculina). Sobre essa mobilidade sazonal, cf. Toral (1992, pp. 63-67), Baldus (1979, p. 165). Hoje, esses deslocamentos estão reduzidos a um mínimo. Ao menos em Buridina, entretanto, penso que ela ainda tem um impacto importante na vida indígena, pois, mesmo que não seja realizada do mesmo modo, ainda há uma diferença nítida de socialidade nos períodos da seca e da cheia ( $c f$. Nunes 2009 , pp. 12-13).

21. Mais precisamente, o termo mekïsêdjê poderia ser seccionado na seguinte forma: $m e=$ « gente », $k \tilde{\imath}=$ « aldeia », sêd = « queimar » e jê é um pluralizador, " gente das aldeias queimadas ». O termo « se refere à prática de queimar tudo em volta, de modo a limpar bem: entre os fundos das casas e as roças ficam apenas os pomares de banana, os pequizais, etc., e não mato ", i.e., ao modo como as grandes aldeias circulares são produzidas (Coelho de Souza, comunicação pessoal).

22. Em outro lugar (Nunes 2012, cap. v) tratei da relação entre a produção de parentesco e a memória entre os Karajá, argumentando que pessoas se produzem reciprocamente como parentes ao lembrarem-se umas das outras, propiciando, assim, fluxos de afetos, palavras, doenças, alimentos, substâncias corporais, enfim, toda a gama de elementos cuja circulação assemelha seus corpos.

23. Os cônjuges trabalham um para o outro, desempenhando atividades complementares. No caso dos homens, isso é geralmente resumido pela injunção da necessidade de « colocar comida em casa $»$.

24. Mais precisamente, vários autores caracterizaram o sistema karajá como de dupla descendência, apontando para a dualidade entre uma afiliação patrilinear aos grupos rituais masculinos ijoi e matrilinear ao espaço doméstico da aldeia (cf. Lipkind 1948, p. 186; Dietschy 1963, p. 44 e 1978, p. 77; Donahue 1982, p. 186-7; Pétesch 1993, p. 373; Toral 1992, p. 18; Fénelon Costa 1978, p. 39). 
25. Os Karajá apresentam uma tendência uxorilocal amplamente documentada na literatura específica (cf. por exemplo, Lima Filho 1994; Toral 1992; Rodrigues 2008). Em Buridina, porém, devido aos casamentos com brancos, parte dos casamentos são virilocais, pois o comum é que, ao se casarem, homens e mulheres tragam o cônjuge tori para morar na aldeia.

26. Os Karajá de Buridina chamam de « umbigo » tanto a placenta e o cordão umbilical quanto a parte deste último que fica colado à barriga da criança (binõti).

27. Luis Cayón (2008) mostra que também a pessoa makuna, se bem que por meios distintos dos Inỹ - uma série de curações xamânicas iniciadas no nascimento da criança e que continuarão a ocorrer ao longo de toda a vida - estabelece uma relação metonímica com vários lugares.

28. A única posição, aliás, para a qual a terminologia de parentesco karajá reserva um termo específico de afinidade: waralyby, genro; literalmente, «meu sobrinho (wara) negro (lyby) » (cf. Dietschy 1978, p. 80; Donahue 1982, pp. 332-333; Pétesch 1992, pp. 372 e 376).

\section{REFERÊNCIAS CITADAS}

Aytai Desidério

1979 «Obstetrícia karajá », Publicações do Museu Municipal de Paulínia, 10, pp. 1-11.

BALDUS Herbert

1948 " As tribos dos Araguaia e o Serviço de Proteção aos Índios », Revista do Museu Paulista, 2, pp. 137-168.

1979 Ensaios de etnologia brasileira, Companhia Editora Nacional, São Paulo.

Bonilla Oiara

1997 Un village sans cimetière: regard ethnographique sur l'établissement d'une communauté Javaé dans un village de colons, Porto Txuiri, Ilha do Bananal (Brésil Central), dissertação de mestrado, Université Paris X-Nanterre, Nanterre.

CARNEIRO DA CUNHA Manuela

1993 «Les études gé », L’Homme, 33 (126-128), pp. 77-93.

CASEY Edward

1996 «How to get from space to place in a fairly short stretch of time: phenomenological prolegomena ", in Steven Feld e Keith Basso (eds), Senses of place, University of Washington Press, Washington, pp. 13-52.

CAYÓN Luis

2008 «Ide ma: el camino del agua. Espacio, chamanismo y persona entre los Makuna », Antípoda, 7, pp. 141-173.

Coelho de Souza Marcela S.

2004 «Parentes de Sangue: Incesto, substância e relação no pensamento Timbira », Mana, 1 (10), pp. 25-60.

2009 Três nomes para um sítio só: a vida dos lugares entre os Kĩsêdjê (Suyá), comunicação, IV congresso da Associação Portuguesa de Antropologia Painel Convidado VII: Classificar: objectos, sujeitos, acções, Lisboa, 9-11 de setembro 2009. 
2011 True endogamy or the outcest taboo (for the Kĩsêdjê) : how kinship (under) determines humans, fala apresentada no seminário Antropologia de Raposa. Pensando com Roy Wagner, Florianópolis, 8-11 de outubro 2011.

\section{DiETSCHY Hans}

1963 "Le système de parenté et la structure sociale des indiens Carajá », in Actes $d u V^{e}$ Congrès international des sciences anthropologiques et ethnologiques, Paris, 1960, t. 2, vol. 1, pp. 43-47.

1978 «Graus de Idade entre os Karajá do Brasil Central», Revista de Antropologia, 21, pp. 69-86.

Donahue George

1982 A contribution to the ethnography of the Karajá indians of central Brazil, tese de doutorado, University of Virginia, Charlottesville.

ERIKSON Philippe

2000 "I", "UUU", "SHHH": gritos, sexos e metamorfoses entre os Matis (Amazônia Brasileira) », Mana, 6 (2), pp. 37-64.

FÉnelon Costa Maria Heloisa

$1978 \quad$ A arte e o artista na sociedade Karajá, Funai, Brasília.

ForTunE David Lee

1973 « Gramática Karajá: um estudo preliminar em forma transformacional », Série Lingüistica SIL, 1, pp. 101-161.

Gow Peter

1997a «O parentesco como consciência humana: o caso dos Piro », Mana, 3 (2), pp. 39-65.

1997b «Land, people, and paper in Western Amazonia », in Eric Hirsch e Michael O'Hanlon (eds), The anthropology of landscape. Perspectives on place and space, Clarendon Press, Oxford, pp. 43-62.

Hirsch Eric

1997 «Introduction. Landscape: between place and space », in Eric Hirsch e Michael O'Hanlon (eds), The anthropology of landscape. Perspectives on place and space, Clarendon Press, Oxford, pp. 1-30.

INGOLD Tim

2000 "The temporality of the landscape » in The Perception of the Environment:

Essays in livelihood, dwelling and skill, Routledge, London, pp. 189-208.

Kelly José Antonio

2011 State healthcare and Yanomami transformations: a symmetrical ethnography, Arizona University Press, Tucson.

Krause Fritz

1943 «Nos Sertões do Brasil », Revista do Arquivo Municipal de São Paulo, 88, pp. 183-205.

LÉVY-BRUHL Lucien

1922 La mentalité primitive. [http://classiques.uqac.ca/classiques/levy_bruhl/ mentalite_primitive/mentalite_primitive_1.pdf, consultou em 04/09/2010]. 
LÉVI-STRauss Claude

1964 Le cru et le cuit, Plon, Paris.

1976 «La geste d'Asdiwal», in Anthropologie structurale deux, Plon, Paris, pp. 175-233.

Lima Filho Manuel Ferreira de

1994 Hetohok-ỹ um rito Karajá, Universidade Católica de Goiás (UCG), Goiânia.

LIPKIND William

1948 "The Carajá », in Julian Steward (ed.), Handbook of South American Indians, vol. 3, Smithsonian Institution, Washington, pp. 179-191.

LOURENÇO Sonia R.

2009 Brincadeiras de Aruanã: performances, mito, música e dança entre os Javaé da ilha do bananal (TO), tese de doutorado, Programa de Pós-Graduação em Antropologia Social (PPGAS)/Universidade federal de Santa Catarina (UFSC), Florianópolis.

\section{Melatti Julio Cesar}

2005 Índios e Criadores. A situação dos Craôs na Área Pastoril do Tocantins, edição do autor, Brasília [1967].

NimuENDAJU Curt Unkel

1946 The Eastern Timbira, University of California Press, Berkeley/Los Angeles.

Nunes Eduardo S.

$2009 \quad$ A cruz e o itxe(k)ò: mestiçagem, mistura e relação entre os Karajá de Buridina (Aruanã-GO), monografia (graduação), Departamento de

2012 Antropologia (DAN)/Universidade de Brasília (UnB), Brasília.

No asfalto não se pesca: parentesco, mistura e transformação entre os Karajá de Buridina ( Aruanã - GO), dissertação de mestrado, Programa de PósGraduação em Antropologia Social (PPGAS)-DAN/UnB, Brasília.

[http://www.dan.unb.br/images/doc/Dissertacao_284.pdf, consultou em 07/08/2013].

Oliveira Tadeu G. de e Katia Cassaro

1999 Guia de identificação dos felinos brasileiros, Sociedade de Zoológicos do Brasil, São Paulo.

PÉTESCH Nathalie

1992 La pirogue de sable. Modes de représentations et d'organisation d'une société du fleuve: les Karajá de l'Araguaia (Brésil central), tese de doutorado, Université Paris X-Nanterre, Nanterre.

1993 «A trilogia Karajá: sua posição intermediária no continuum jê-tupi », in Eduardo B. Viveiros de Castro e Manuela Carneiro da Cunha (eds), Amazônia: etnologia e história indígena, Núcleo de história indígena e do indigenismo (NHII), Universidade de São Paulo (USP)/Fundação de Amparo à Pesquisa do Estado de São Paulo (Fapesp), São Paulo, pp. $365-381$. 
Pimentel Da Silva Maria do Socorro e Leandro Mendes Rocha

2006 Linguagem especializada: mitologia Karajá, UCG, Goiânia.

Praet Istvan

2009 «Shamanism and ritual in South America: an inquiry into Amerindian shape-shifting », The Journal of the Royal Anthropological Institute, 15, pp. 737-754.

RIBEIRo Eduardo Rivail

2012 A grammar of Karajá, tese de doutorado, departamento de linguística, University of Chicago, Chicago.

RoDrigues Patrícia

1993 O povo do meio: tempo, cosmo e gênero entre os Javaé da Ilha do Bananal, dissertação de mestrado, PPGAS-DAN/UnB, Brasilia.

2008 A caminhada de Tan-ỹxiwè: uma teoria Javaé da história, tese de doutorado, departamento de antropologia, University of Chicago, Chicago.

SeEger Anthony

1980 "Corporação e corporalidade: ideologia da concepção e descendência ", in Os índios e nós. Estudos sobre sociedades tribais brasileiras, Editora Campus, Rio de Janeiro, pp. 125-132.

1981 Nature and society in Central Brazil. The Suyá Indians of Mato Grosso, Harvard University Press, Cambridge.

SeEger Anthony, Roberto DaMatta e Eduardo Viveiros de Castro

1979 "A construção da pessoa nas sociedades indígenas brasileiras », Boletim do Museu Nacional. Antropologia, 32, pp. 2-19.

Toral André Amaral de

1992 Cosmologia e sociedade Karajá, dissertação de mestrado, PPGAS-Museu Nacional, Universidade Federal do Rio de Janeiro (UFRJ), Rio de Janeiro.

TURNER Terence

1993 «Da cosmologia a História: resistência, adaptação e consciência social entre os Kayapó ", in Eduardo B. Viveiros de Castro e Manuela Carneiro da Cunha (eds), Amazônia: etnologia e história indígena, NHII-USP/Fapesp, pp. 43-66.

VILAÇA Aparecida

2000 «O que significa tornar-se outro? Xamanismo e contato interétnico na Amazônia », Revista Brasileira de Ciências Sociais, 15 (4), pp. 56-72.

2005 "Chronically unstable bodies: reflections in Amazonian corporalities », The Journal of the Royal Anthropological Institute, 11 (3), pp. 445-464.

2007 "Cultural change as body metamorphosis », in Carlos Fausto e Michael Heckenberger (eds), Time and memory in indigenous Amazonia. Anthropological perspectives, University of Florida Press, Gainesville, pp. 169-193.

Viveiros de CASTRo Eduardo B.

1996 « Os pronomes cosmológicos e o perspectivismo ameríndio », Mana, 2 (2), pp. 115-144. 
2002 «Perspectivismo e multinaturalismo na América indígena », in A inconstância da alma selvagem, Cosac \& Naify, São Paulo, pp. 345-399.

WüsT Irmhild

1975 " A cerâmica Karajá de Aruanã », Anuário de Divulgação Científica, 2 (2), pp. 95-165. 